as inequalities among citizens have escalated. Again, the material draws on the work of other scholars, but Diamond suggests, interestingly, that US citizens may be more religious than those of other industrialized nations because of the high levels of economic inequality in their country (religion helps to rationalize prosperity for those at the top of the ladder and mitigate adversity for those at the bottom).

Finally, in a chapter on health, Diamond recapitulates arguments for the 'diseases of civilization' - that the fats and salts we consume do not suit physiologies designed for foraging, and cause the hypertension and diabetes crises that we see in populations transitioning to modern lifestyles. With reference to James Neel's 'thrifty gene' hypothesis, Diamond attributes the particularly high incidence of type 2 diabetes among Pima Native Americans and Nauruan Pacific Islanders to catastrophic recent famines in these populations, which may have favoured the survival of individuals who most efficiently converted sugars to fats. He also proposes that Europeans may have been through a gradual and largely undetectable diabetes crisis, starting in the fifteenth century, as food security increased with the development of state distribution systems - with Johann Sebastian Bach named as one possible victim.

Diamond has an engaging style, and has packed the book with grisly anecdotes and delightful detail from the jungles of New Guinea to the strip malls of Los Angeles, California, alerting us to grim realities of the industrial world. For example, a single pan-fried-noodle combo dish served in Los Angeles contains more than a year's worth of a Yanomami Indian's salt intake. The book brings anthropology alive for those who have never had the privilege of visiting, or reading deeply about, societies very different from their own. For those who have worked in the remote reaches of the world, it may tire or even annoy. Tire, because the book is long, and draws on overly familiar ethnographies; annoy, because the scale of comparison, us versus them, is conceptually limiting.

Diamond has previously described his writings on the cultures of New Guinea as journalism. Perhaps this is how we should read The World Until Yesterday, as a highly personal reflection on the virtues and vices of modern industrial civilization.

\section{Monique Borgerhoff Mulder is a}

human behavioural ecologist at the University of California, Davis, USA. e-mail:mborgerhoffmulder@ucdavis.edu

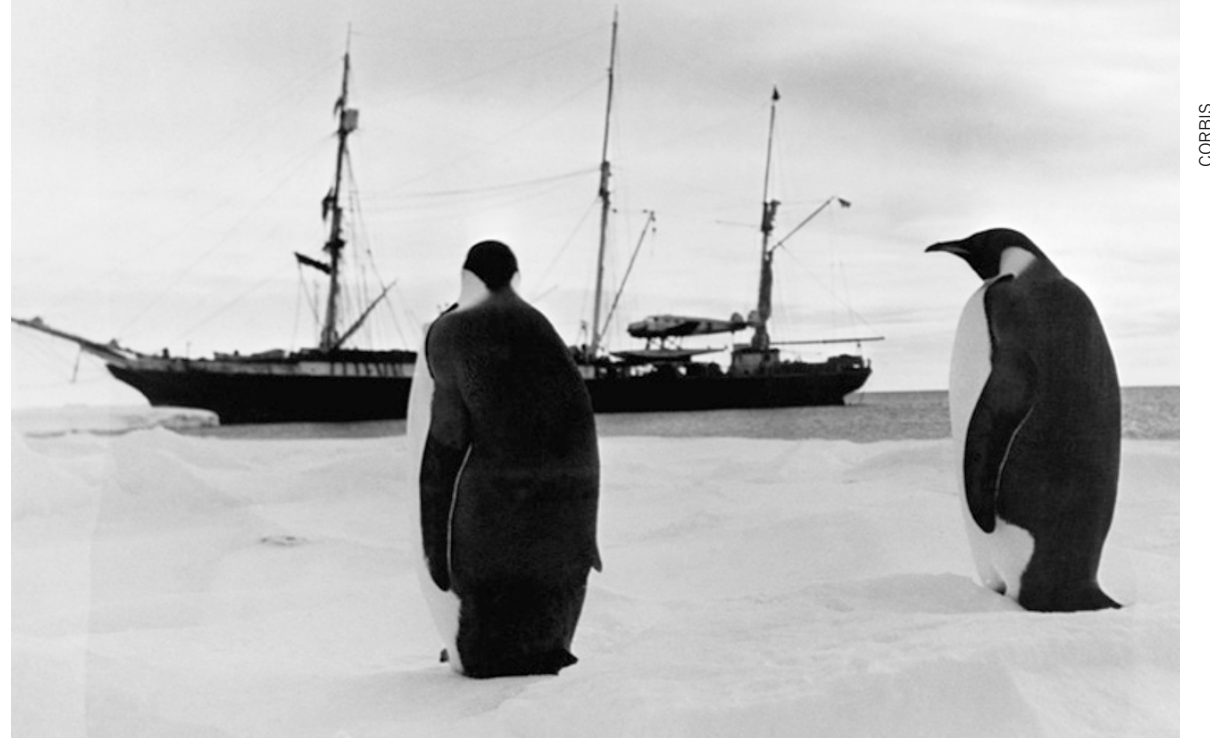

One of the vessels captained by US explorer Richard Byrd in Antarctica in the 1930s.

HISTORY

\title{
Frozen assets
}

\section{Edmund Stump welcomes a history of Antarctica that covers the glory, the rivalries and the scientific legacy.}

$\mathrm{F}$ Trom James Cook's circumnavigation of Terra Australis Incognita in 1772-75 to today's shifting international population of researchers, Antarctica's history is stamped by the continent's remote isolation, extreme climate and scientific importance. Its strategic and economic potential have not escaped government attention. Behind the scenes, nations have long plotted to win sovereignty and control resources. And that is where David Day's Antarctica: A Biography takes us, into a two-faced world of public and covert intentions where personal and national rivalries abound.

Antarctica is the first comprehensive history of the continent, spanning the centuries since Cook's voyage. The heroic expeditions of Robert Falcon Scott, Roald Amundsen and other luminaries are all there, as are many that are less well known. Day couches these throughout in political contexts how they served the motives of the colonial offices or state departments back home. The dramas, played out in secret memos and in published statements in newspapers, give the book a slow, even glacial, pace at times.

At every turn there is hesitancy on the part of diplomats and leaders: to claim or not to claim, to recognize others' claims or not, to offend trading partners or not, to respond to official memos or to let them go unanswered. In this way we have collectively backed into today's Antarctica, where all territorial claims are held in abeyance, a 50-year moratorium prohibits exploration for mineral and energy resources, and tourists flock in droves.

\section{Day has done a Antarctica:} remarkable job of ABiography collating information from rich and varied international sources. DAVID DAY Oxford Univ. Press: 2013. 624 pp. £25 He draws from original accounts, newspaper articles, the recently released papers of US naval officer and polar explorer Richard Byrd, and numerous national archives with their copious committee reports and memos, some recently declassified.

The concealment of who made what claims where and when, and how different versions were presented to the public, dominate the book. One example is what Byrd told reporters in Dunedin, New Zealand, after his first Antarctic expedition (1928-30). Although he said he was "not the least concerned with claiming the land for America", he had recently photographed miles of mountains and coastline in Marie Byrd Land with just that intent. He had also instructed Laurence Gould, his second in command, to leave a note in a cairn claiming the territory for the United States when Gould's ground party traversed beyond the boundary of $\mathrm{New}$ Zealand's Ross Dependency.

Although I am familiar with the history of exploration in the Peninsula and Ross Sea sectors of Antarctica, Day expanded my horizons to the 'African' sector, the section of East Antarctica facing the tip of Africa. Here, between the world wars, Norwegians led the last great slaughter of Antarctic whales and mapped major sectors of the coastline, infringing on claims by the ever-vigilant 
Australians. During the 1929-30 summer season, for instance, the Norwegians and Australians converged on Enderby Land intent on extending their claims to the same territory and forestalling the other's.

I also enjoyed the account of the jostling at Deception Island during and immediately after the Second World War, when Argentina painted its colours on the abandoned British station. After the British removed them, subsequent claims were made by Chile and Argentina, ultimately leading to 'Operation Tabarin' - a secret UK mission charged with building and maintaining permanent British stations on the Peninsula. Following the war, scientific activity increased and responsibility was transferred to the Falkland Island Dependencies Survey, which in 1962 became the British Antarctic Survey.

Each chapter covers a specific period in dense detail. There is grist here for the ruminations of historians, although a more casual reader might find it hard to digest at times. But the final chapter, covering the period since the 1961 signing of the Antarctic Treaty, breezes through the turning points.

I was reminded of how, in June 1988, the Convention on the Regulation of Antarctic Mineral Resource Activities had been adopted and was poised for ratification by the treaty nations. Then, in January 1989, the Argentinian ship Bahia Paraiso ran aground off the Antarctic Peninsula, spilling oil into the surrounding waters. Two months later, the Exxon Valdez went down in Prince William Sound, Alaska, emptying 260,000 barrels of crude oil into similarly frigid waters. Countries that had quietly endorsed the convention scrambled to withdraw their support, and within two years the Protocol on Environmental Protection to the Antarctic Treaty (the Madrid Protocol), was in place, prohibiting the exploration and exploitation of mineral resources on the continent for 50 years.

But marine resources remain a contentious issue, as witnessed by the failure in Hobart last year of the Commission for the Conservation of Antarctic Marine Living Resources to establish proposed marine reserves in critical areas in the Southern Ocean.

Day ends by saying, "For centuries, the Antarctic defied man's approach. Now its dangers and its terrors have been largely conquered. Only its future remains unknown." I would add that, thanks to Day, the intrigues and posturing that saturate the history of this distant land have now been exposed. We are left to wonder what continues to be plotted behind the scenes.

Edmund Stump is a professor of exploration at Arizona State University who has led many Antarctic field projects. He is the author of The Roof at the Bottom of the World: Discovering the Transantarctic Mountains. e-mail:ed.stump@asu.edu

\section{Books in brief}

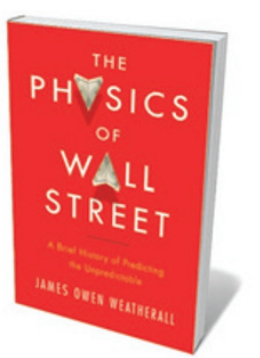

The Physics of Wall Street: A Brief History of Predicting the Unpredictable

James Owen Weatherall Houghton MiffLIN HARCOURT 304 pp. $\$ 27$ (2013)

Wall Street's 2008 meltdown is often pinned on 'quants', the physicists and mathematicians who invented financial instruments such as derivatives. Physicist James Owen Weatherall argues that it was less about the models than a catastrophic misuse of them. He bolsters his view with a concise history of scientific bravehearts out to tame the market, from Louis Bachelier, pioneer of the maths of financial markets, to recent risk-wranglers such as Didier Sornette.

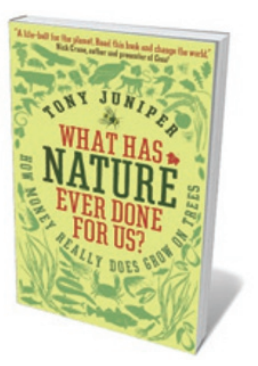

What Has Nature Ever Done For Us? How Money Really Does Grow On Trees

Tony Juniper PROFILE BOoKs 256 pp. £9.99 (2013)

Microbes restore soils, trees oxygenate the atmosphere, vultures act as sanitation crews. And, says Tony Juniper in this crisp call to action, such 'ecosystem services' could back the currency of a new economics. The concept is hardly new, but Juniper - former head of Friends of the Earth - declares its time has come. As he trawls the biosphere and its rich array of services, his insights on environmental threats and solutions, backed by robust findings, form a pragmatic argument for a return to 'gardening the Earth'.

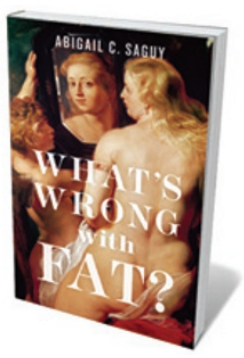

What's Wrong with Fat?

Abigail C. Saguy OXFORD UNIVERSITY PRESS 272 pp. \$29.95 (2013) Obesity is an international epidemic. Or is it? Sociologist Abigail C. Saguy weighs in with an investigation of fatness that looks provocative, yet is thoughtful and thorough. By examining heft through many lenses, from the ethical to the scientific, Saguy traces how labelling fat as a disease or as an indicator of immorality seeps into society. She argues that public-health diktats are issued despite scientific debate over the condition; and that factors in fatness, such as poverty, are often ignored. Ultimately, she avers, stigmatizing the condition serves to embed it further.

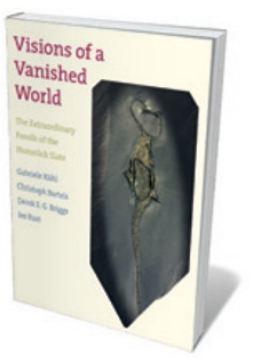

Visions of a Vanished World: The Extraordinary Fossils of the Hunsrück Slate

Gabriele Kühl, Christoph Bartels, Derek E. G. Briggs and Jes Rust YALE UNIVERSITY PRESS 128 pp. $\$ 40$ (2012)

Some 400 million years ago, catastrophic storms and seismic shifts may have triggered the release of a vast slick of sediment that buried thousands of soft-bodied marine organisms on the ocean floor. Germany's Hunsrück Slate is the result: a frozen slice of the Devonian, capturing trilobites, ammonites and more in their last second of life. Pyritization has left exquisitely detailed, golden-hued fossils, hauntingly displayed in this coffee-table volume.

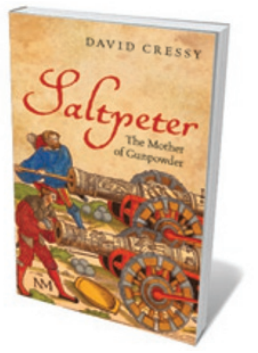

Saltpeter: The Mother of Gunpowder

David Cressy OXFORD UNIVERSITY PRESS 356 pp. £16.99 (2013)

Gunpowder obsessed early-modern Europe and Islamic Asia. But its key ingredient — potassium nitrate, or saltpetre — had either to be extracted from excrement- and urine-drenched soils, or imported. The scramble to get enough is the focus for this science-tinged history of a Britain building up to empire and enlightenment. David Cressy tells the tale of this "crucial link in the chain of chemistry and power" with panache, from the unravelling of saltpetre's chemistry to the warmongering that fostered dependence on it. 